\title{
Islamic Criminal Applications in Article 292 and Homosexual HIV/AIDS Treatment in Padang City
}

\author{
Yusnani $^{1}$, Welsi Haslina ${ }^{2}$, Magfirah $^{3}$ \\ \{yusnani57@gmail.com¹, welsih@yahoo.com², magfirah616@gmail.com ${ }^{3}$ \} \\ 1,2 Padang State Polytechnic Accounting Department \\ ${ }^{3}$ Faculty of Social and Political Sciences of Postgraduate Unand Padang
}

\begin{abstract}
The Criminal Code article 292 (KUHP) regulates that adults who commit immoral acts of homosexual immature are punishable by imprisonment for a maximum of five years. Al-Qur'an and AlHadith are qath'i (decisive) and muhkamat (clearly the legal provisions) strongly oppose this behavior. Allah refers to homosexual acts as liwath (condemnation) which accuses the culprit of being executed or suffocating or being dropped from a high place. This study applied the concept of scholars and City government. Government Health Office on the prevention of homosexual HIV/AIDS in the city of Padang. The combination of qualitative approaches results in policy recommendations. This research uses descriptive method with a comparative analysis deepening. The city government of Padang has not yet implemented the Law article 292 which is a five-year criminal law or takzir law (sentenced to ten years in prison) both adults and children under the age of 15 years. The cleric's call to improve aqidah and morals immediately repent and get married, the new health department conducts counseling and consciously self-check medical treatment and use condoms.
\end{abstract}

Keywords: Article 292, HIV/AIDS, Homosexual, Islamic Criminal

\section{Introduction}

The State of Indonesia is a state of law based on Pancasila by upholding the values of morality, ethics, noble character, and the noble personality of the nation, having faith and devotion to God Almighty, respecting diversity in community life, nation, state, and protecting the dignity and dignity of each citizen (Government of Indonesia, 2016) [1].

In Indonesia's positive law, same-sex sexual relations are regulated in article 292 of the Indonesian Criminal Code (KUHP) stipulates that adults who commit obscene acts with others of the same sex, who are known and should be immature are threatened with imprisonment of up to five year. (KUHP AND KUHAP Constitutional Court Decision Number 9 / PUU-V / 2007 Regarding Amendments to Articles 154 and 155 of the Criminal Code, 2019: 102). (Setyawan, 2015) [2].

Sexual activity has a multi-purpose property in addition to following the natural will that is instinctive, the will of the Almighty is also a sign of the practice of the sunnah and meet the needs that really need to be implemented. The problem of homosexuality in Indonesia is considered a taboo for the public and the government because there is rarely public discussion discussing sexuality issues in any form specifically about homosexuality openly. As well as the community's assessment of religious views is considered a sin, from a medical point of view it is considered an illness, according to the law it is considered a criminal, and the community considers it a social deviation. The existence of cyiber sex crimes opens 
opportunities in cyberspace to develop increasingly dirty sexual deviations and commit adultery very easily and there is no clarity of the law in the Criminal Code for single adulterers, except for adulterers who have been married if the status of husband or wife in article 284 of the Criminal Code is convicted for nine months However, homosexual crime can only be punished if it is carried out on a minor if an adult does not have an article regulating it.

The problem of homosexuality in Indonesia is considered a taboo for the public and the government because there is rarely public discussion about sexuality issues in any form specifically homosexuality openly. As well as the community's assessment of religious views is considered a sin, from a medical point of view it is considered an illness, according to the law it is considered a criminal, and the community considers it a social deviation. The existence of cyiber sex crimes opens opportunities in cyberspace, the development of sexual deviations that are very dirty and commits adultery is very easy and there is no legal clarity in the criminal code for single adulterers, except for adulterers who have been married if the status of husband or wife in article 284 of the criminal code is convicted for nine months. However, homosexual crime can only be punished if it is carried out on a minor if an adult does not have an article regulating it.

Homosexuals are sexual relations between men and men, women while to have sex between women, is called lesbian (female homosex). Homosexual and lesbian opponents are heterosex, meaning sexual relations between people who are different sexes (a man and a woman). In Islamic law, gay men are called liwath whose root is the same as the root of Lut. Deed gay men are called liwath, because of deeds that was done by the disobedient to the appeal Prophet Lut (as). The people live in the land of Sodom (next door) east of the Dead Sea or in Jordan now) and therefore in westerners who are Christians do deeds thus called sodomy (Yanggo, 2019) [3].

Transsexuals in a psychological context are included in transsexualism, namely someone who is physically clear and perfect, but psychologically tends to present themselves as opposite sex (Koeswinarno \& Mustolehudin, 2017) [4]. Transsexualism is an individual with a gender identity disorder which generally starts from childhood where he feels and believes that he is the opposite sex with his true condition. This feeling continues from childhood to adulthood. (Coulter, Kenst, Bowen, \& Scout, 2014) [5].

Sex is not only about ejaculation for a man. The most important thing is harmony and the similarity of heart, and not necessarily every time, and not at other times. But at the time of bodily pleasure wrestling incredible joy not only during orgasm. A man can have the power to gain satisfaction in orgasm with the woman he loves. (Che Zarrina binti Saari, 2015) [6].

The other meaning of sex is more emphasized on the anatomical state of man which then gives "identity" to the person concerned. Someone who has the anatomy of the penis is called a male. Whereas people who have vaginal anatomy are called women. The term sex is generally used to refer to issues of reproduction and sexual activity. Because the emphasis is more on things that are anatomical, then sex is often interpreted narrowly as a bodily relationship between men and women. The sex instinct itself is the most powerful instinct, which demands distribution. If distribution cannot be satisfying, then people will experience 
shock and loss of control to control their lust, and there arises sexual relations outside the provisions of the law, such as, one of them homosexual (Rangkuti, 2012) [7].

By nature male and female instincts have a strong appeal. This is the first basis in the bond between types of people to go to happiness, that is a sense of helps in maintaining honor and enduring the fatigue of life. (Isa, Fahmi, Yahya, \& Jasmi, 2012) [8]. Islam believes that the obligation of the father and his guardians towards his daughter is to nurture his morals. Morals are the highest part in the human psyche and appear all the behavior of people both praiseworthy and despicable. (Abu Bakar Jabir al Jaza'iri, 2018: 216). Morals must always be fostered and educated properly and correctly in order to like the good and keep away the despicable QS: al-Ahzab: (33): 21 and QS: al-Qalam: (68): 4.

\section{Discussion}

\section{Sexuality In Islamic Criminal Laws And Laws In Indonesia}

\subsection{Islamic and Sexual Criminal Law}

Islamic criminal law can be divided into two, some call it jinayah fiqh and some call it a fiqh book whose explanation is complete. The book specifically named jinayah fiqh has a more detailed, actual and accommodative discussion system (Nurul Irfan et al, 2013: 1). The main study jinayah fiqh there are three parts, namely 1) al-rukn al-Syar'i or formal elements namely elements that state that a person can be said to be a Jarimah (criminal act) if there is a law that expressly prohibits and imposes sanctions on the perpetrators of acts criminal. 2) Al Rukn almadi or material element is an element which states that a person can be convicted of a criminal if it is truly proven to do a good rahmah (active in doing something) or negative nature. 3) Alrukn al-adabi or moral element which states that a person can be blamed if he is not a crazy person, a minor or is under threat.

There are five norms underlying Islamic law. Shatibi categorizes the discussion: First, mubah, which does not result in merit or sin, leaving or doing mubah deeds is utterly commendable or despicable. Shatibi's discussion is directed to the Sufis that something that changes makes people complacent about worldly pleasures and forgets the afterlife. Both actions are initially changed but on a broad scale it is mandatory for example a husband may not have intercourse within a certain time because there is an emergency reason. The three actions which have status but on a large scale become makruh like singing continuously. Finally, actions at a particular time change but within a broad framework it becomes haram and sterile (sunnah) (Hallaq, 2001) [9].

Sexual arrangements in Islam as adultery and forbid means and intermediaries such as sexual disorders known as liwath (homosexuals). This behavior is a deviation of nature destroying manhood to forget the morals, customs and reasonable tastes .(Siti Aminah, 2015) [10].

This heinous act is explained in the Qur'an: " 
"Why do you come to the type of man among men, and you leave behind wives who are made by your Lord for you even you are truly transgressors "(QS: Asy-Syu'ara verse: 165166).

Fiqh scholars differ in passing homosexual punishment as compared to the punishment of adultery or being killed or thrown from a tall building, this punishment seems cruel but in order to save the destruction and destruction of humanity. Islamic law views every sexual relationship outside of marriage as adultery and threatens it with punishment, whether the perpetrator is married or unmarried, done like it or not (MUSLICH, 2001) [11].

In Islam, adultery is categorized as a heinous act and damage offspring. There are two kinds of adultery, namely adultery gairu muhsan is adultery committed by free men or women (not slaves) who are not married or have no family. Punishment for perpetrators of adultery ghairu muhsan is flogged 100 times and thrown out of the area for one year for those who are free, and half for slaves.

Adultery muhsan, which is adultery committed by men or women who have never been married or are still in a state of marriage and independence. The punishment for zina muhsan is stoning. Allah SWT says in the Qur'an, surah Al-Israa 'verse 32: "And do not approach adultery; indeed adultery is a cruel act. And a bad road ".

Islam requires normal sex through marriage with the intention to devote all of his time to worship Allah SWT. To overcome the damage to the soul and direct the noble character, Islam wants human nature to go according to the will of the Almighty. Only Islam does not agree with the view that curbing sexual instincts naturally cannot be attributed to the high degree and value of one's glory.

The Word of God in the Qur'an QS: 54: 21 the process by marriage.

"And among the signs of His power is that He created for you wives of your own kind, so that you tend and feel at ease with him, and make Him among you of love and affection. Verily in that are indeed signs for people who think "(Surah Ar-Rhuum: 21).

Departing from the duties and obligations of Muslims as servants of God who serve, worship and worship Him, then all forms of life as a whole and in total for a Muslim is for and for service itself. Sex part of human sex life can be a happy pleasure can also be a beginning of destruction and misery (Che Zarrina binti Saari, 2015) [12].

There are two fundamental facts that determine the sexual strategy of Muslim societies in the coming decades. Firstly, their dependence on the economy made the country's bourgeoisie unable to work for a group of people with the highest number of births in the world. Secondly, Muslim culture has been arranged in an ideological blindness to the economic dimension of women, which can normally be understood to be imagined and defined as specifically sexual targets (Che Zarrina binti Saari, 2015) [13].

Lust is part of God's creature. Armed with lust also humans can run their lives naturally as creatures that live in the natural world. Various important human needs, such as eating, drinking, sleeping, getting married, etc., involve lust in them. Lust is not an absolute bad thing. However, lust has tendencies to deviate. Because of that, in Islam there is a strong suggestion 
to control lust. Indeed humans are not ordered to destroy it, but lust must hold full power to be saved from the pitfalls and temptations that plunge.

There are only two choices, to control lust or to be controlled by lust. These two choices also determine whether to get ultimate happiness or not. Imam Abu Hamid al-Ghazali once said in the book of Ihy 'ûlumiddîn: "Happiness is when someone is able to master his lust. Misery is when someone is controlled by their desires. " (Hajriansyah, 2017) [14].

The Islamic view of sexuality in this writing is human behavior that is rightly blessed by Allah SWT in accordance with his nature, lives in harmony and can meet the demands of life normally without ignoring other needs.

In principle in Islam there are two main objectives of the institution of marriage. First, get peace of mind, avoid anxiety, and indecision that does not end. Second, giving birth to pious children/salihah, Allah SWT said:

"O people, fear your Lord who created you from one self, and from this Allah created his wife; and from both of them God multiplied many men and women. And fear Allah, by (using) His name, you ask one another and (nurture) a relationship of friendship. Verily, Allah always takes care and watches over us "(QS. An Nisaa: 1).

"Allah made for you wives of your own kind and made for you from your wives, children and grandchildren, and gave me fortune from the good. So why do they believe in the vanity and deny the favor of Allah? "(Surat an-Nahl:72).

Allah Almighty gives sexual freedom freely in accordance with His word:

"Your wives are (like) the land where you plant, so come to the land where you plant it however you wish. And do (good deeds) for yourself, and fear Allah and know that you will meet Him someday. And give good tidings of those who believe "(Surah Al Baqarah: 223).

The above evidence shows, that sexual is a human nature that must be channeled through marriage. This is intended to create a sakinah, mawaddah and warahmah family. Marriage (marriage) according to the meaning of the term is sexual relations but the meaning of majazi (methaporic) or legal meaning is a marriage contract that makes lawful sexual relations as husband and wife between a man and a woman.

According to Imam Shafi'i, the meaning of marriage is according to the meaning of language of intercourse or marriage and bonding or marriage. Marriage is wath '(gathering) and according to sharia terms is a contract that allows intercourse provided conditions and harmony are met (Mursyid, 2015) [15]. While Hazairin said that the essence of marriage is sexual relations, according to him there is no marriage (marriage) if there is no sexual relations.

From the various meanings above, marriage connotes sexual relations between men and women. Therefore it can be concluded that halal sex in an Islamic perspective is sex between men and women through marriage.

\section{Sexuality in Laws in Indonesia}


The State of Indonesia is a State of law based on Pancasila by upholding the moral values, ethics, noble character and noble personality of the nation, having faith and devotion to God Almighty, respecting diversity in the life of the nation and state, and protecting, dignity and dignity of each citizen.

In Article 3 of the Law aims to a) realize and maintain the order of the lives of people who are ethical, noble personality upholding the value of the Godhead and respecting human dignity; b) respect, protect and preserve the artistic and cultural values, customs and religious rituals of Indonesia's diverse society. (Government of Indonesia, 2016). The construction of sexuality in legislation in Indonesia is stipulated and regulated in the 1945 Constitution, Burgelijik Wetbook / Civil Code, Criminal Code, Law No. 1 of 1974 concerning Marriage, Compilation of Islamic Law (KHI) for Muslims in Indonesia, and other laws. In the 1945 Constitution article $28 \mathrm{~B}$ of the 1945 Constitution states that: "every person has the right to form a family and continue descendants through a legal marriage". In article 2 of Law No. 1 of 1974 stated that a legal marriage if carried out according to the law of each religion and belief (Law No. 1 of 1974 concerning Marriage and Compilation of Islamic Law: 35).

In Indonesia alone, homosexual marriage is not recognized by Indonesian law. Based on Article 1 of Law Number 1 of 1974 concerning Marriage ("Marriage Law"), marriage is a physical bond between a man and a woman as husband and wife.

Article 1 Marriage Law:

"Marriage is an inner bond between a man and a woman as husband and wife with the aim of forming a happy and eternal family (household) based on the Almighty God. "(Law Number 1 of 1974 Concerning Marriage and Compilation of Islamic Law: 3).

There is no legality for homosexuals. There is a discourse prohibiting homosexual acts to be included in the Criminal Code Bill. So far the Criminal Code prohibited only homosexuals committed against minors. Article 292 of the Criminal Code (KUHP) does not expressly prohibit homosexual acts between adults, it is necessary to affirm the prohibition of homosexuality, and adultery.

Article 292 of the Criminal Code which reads:

"People who are old enough, who commit obscene acts with other people of the same sex, are known or should be suspected, that they are not old enough, threatened with imprisonment for a maximum of five years" (Hariansah, 2018)[16].

Of Article 292 of the Criminal Code criminal snares for homosexuality do exist, that is if it is done by an adult with a minor of the same sex. However, having the nature of liking or attraction to same-sex is not convicted, but if followed by obscene acts, then the perpetrators can be sentenced to five years in prison. In article 290 of the Criminal Code the threat of imprisonment is no longer than seven years: Whoever commits obscene acts with a person even though he knows or deserves to be suspected, that he is not yet fifteen years old or if his age is unclear, the relevant person is not yet to be married. (Criminal Code) and KUHAP SPMK Number 9 / PUU-V / 2007: 101-102). (Toomey, Ryan, Diaz, Card, \& Russell, 2010) 
The deterrent effect for the same criminal community is added by one third if the obscene acts are carried out by means of oral sex or anal sex or all forms of meeting non-genital organs with genitals committed homosexually. The Padang City Health Office has its own program to provide guidance by organizing regular programs with outreach to the public, high-risk people and other stakeholders. In addition, the Health Office collaborates with NGOs and the KPA (AIDS Eradication Commission) to facilitate the outreach of homosexual men .

This was revealed by E, on Monday 19 September 2019 as follows:

"...... ..From the Health Office we are working with NGOs and KPA to conduct socialization and provide information related to the dangers of homosexual behavior so that it can raise awareness for key populations. We do not meet directly with key populations the way we provide facilities in several health centers and hospitals to provide counseling services afterwards, if they are positive, there will be VCT services and ARV treatment. (E, September 2019, Padang City Health Office).

Whereas the statement from A who specifically handled the HIV program at the Padang City Health Office on September 27, 2019 stated as follows:

"We provide socialization at every meeting in several Puskesmas, usually once every three months so that we can continue to communicate and monitor their progress so as to foster a feeling that they are accepted and cared for afterwards patients who are HIV / AIDS positive can be referred to several Puskesmas that have served VCT examinations and ARV treatment, namely BP and BS Puskemas or in M.djamil and Yos hospitals. For this routine outreach we provide expert staff who are trained in advance so that they are able to deal with and deal with homosexual behavior that results in HIV / AIDS. (A 27 September 2019, Padang City Health Office).

Communication "Head of the Disease Control and Eradication Division (P2P) of the local Health Office of Gentina in Padang, Wednesday, said of 370 HIV positive cases 257 cases were reports from M Djamil General Hospital."

The Health Service does not directly face homosexuals but instead forms a special team and is trained in advance to be able to approach by conducting socialization in advance and cooperating with NGOs and KPAI Padang city to do networking and embracing them so that they wish to conduct examinations at the Puskesmas so that can reduce the spread of HIV/AIDS.

According to the explanations $\mathrm{E}$ and $\mathrm{A}$ that the special team that has been trained will be able to provide counseling the goal is to approach persuasively so that homosexual men who do counseling are happy to tell stories and feel accepted so that whatever is in their minds can be expressed to the special team called also counselor. If in the counseling activities of homosexual men already feel close and comfortable then the counselor will find a reason why they do the act and find solutions so that it can inhibit the growth of HIV / AIDS from deviant behavior.

The approach taken by counselors to homosexual men is adjusted to their behavior so that the message conveyed can be well received. For example, if a homosexual man is an entertaint, the counselor approaches with relaxed communication and lues so that the consultation process can go well because of the feedback given. It is different if a homosexual 
man is a stiff person and looks so closed then the counselor will talk a lot to make them feel comfortable and in the end tell what they are going through and what are the reasons that make them do such deviant behavior.

Counselors at the BP Health Center on 30 September 2019 said that so far the actions taken in counseling activities for homosexual men were a persuasive approach in order to make them comfortable telling stories and looking for the root causes of deviant behavior. It is not easy to awaken homosexuals so as not to engage in male sex acts with men, but counselors admit that if they are forced to change right then they will not go back to the counseling process. To avoid termination of counseling, the counselor prefers to keep making them feel they need the counselor to tell with the passage of time the counselor will analyze the problems they face and what type of message is most appropriate to get a positive response from the homosexual man so that it will eventually lead to changes in habits. and their attitude.

"When the counseling process takes place, we see how their character is, if they are a bit harsh, we soften if they really enjoy the conversation, then the counseling process can continue. we create the atmosphere of the room as comfortable as possible and foster trust for them so that whatever complaints they want to say can be expressed this can be seen from the response they gave during the consultation process "(SS, 23 September 2019, Puskesmas BP).

Likewise with counselors at the BS Puskesmas they use the same approach in order to be able to analyze what causes a person to engage in deviant behavior, preferring the same sex to men, more precisely sex with men.

"We will see how they respond after we deliver a number of messages, whether exited or not interested in what we are talking about, if they are very interested, then we will convey a message that will make them respond more, otherwise we will find ways to get them interested and give the response. The response in question can also be seen from how their sitting position is where their eyes look at how their body movements ". (R, 24 September 2019, Puskesmas BS).

If the counselor already knows what kind of response they get from homosexual men then there will be a way to approach persuasively so that homosexual men are able to open up and tell everything that causes them to become same-sex lovers. Although this process is long and does not immediately make them change their behavior, at least the counselor always emphasizes that sex with men will have a very dangerous impact such as HIV / AIDS so they must be safe so as not to raise the growth chart of sexually transmitted diseases.

The results of the author's interview with the scholars suggested immediately repent and draw closer to God. Trying to be grateful for the blessings given by God in the form of the perfection of human creation is not to be abused with despicable acts like liking fellow sex. (Interview, September 30, 2019).

LGBT content on Instagram influences the perception of young people in behavior. This is known through a survey of Instagram users of young age groups in Bukittinggi City. For each item on each indicator as a whole it is equally dominant to agree, which is a surprising statement. But once there is a statement on the indicator that there are dependent variables choose less agree on the independent variable. This is what then through statistical calculations 
the effect is not large, that is, it only influences $46.5 \%$, which is classified as moderate. (Lewis, Gonzalez, \& Kaufman, 2012).

From the discussion above, the author states that the previous study of the draft Law article 485 on the crime of single adultery, namely a couple who gathered together in West Sumatra, is proposed to be sentenced to a maximum of one year or a fine of Rp. 50 million. But until now it could not be used as a source of criminal law for the policies of the municipality of Padang. The connection with this research is that there is a suggestion for article 292 on criminality for perpetrators of male-female or homosexual gatherings, which in this article is only applied to minors if the adult culprit is not convicted, this has not been done maximally in the Criminal Code, whereas in Islamic law this act is punishable by adultery, it's just that sexual intercourse takes place between men among men, of course the whip law applies during the time of the people of the Prophet Lut as punished by God Almighty with hail to death.

The influence of homosexual disease is very large in the community especially supported by the advancement of information media both mobile internet and television that inform the lifestyle of many homosexuals (gay). Which has an impact on the transmission of the deadly HIV and AIDS.

\section{Conclusion}

1. Efforts to tackle HIV / AIDS for the new health department are only counseling and invite NGOs to make awareness of homosexuals to be aware of going to the nearest Puskesmas or hospital, and to anticipate the spread of the disease by administering drugs and condoms.

2. Opinion scholars suggest to repent immediately and give thanks for the favors of the perfect nature of human creation by pairing up with a married couple.

3. Revising article 292 of the Criminal Code on criminal law for homosexuals who commit sexual intercourse is sentenced to five years and applies to homosexual sufferers of adults or children under the age of fifteen years or sentenced to a maximum of ten years imprisonment in lieu of takzir law in order to have an effect deterrent.

4. According to Islamic criminal law equated with criminal adultery applies whip law for single sufferers and stoning for those who have been married or killed.

\section{Suggestion}

1. To the Padang City Health Office further enhance socialization to the public of the dangers of HIV / AIDS due to same- sex relationships or Male Fellow (Gay).

2. Hoping that the Padang city government applies Article 292 regarding the criminal law of homosexuals who commit obscene both adults and children are criminalized. For example, can be seen in the Painan District Court Decision Number: 64 / Pid.Sus / 2018 / PN.Pnn, where the defendant has been proven legally and convincingly guilty of committing a crime "with the threat of violence committing obscene acts" against a child committed by forcing sexual intercourse through the anus on 3 boys (sodomy). As a result of the defendant the defendant was sentenced to imprisonment for 6 (six) years and a fine of Rp. 60 million provided that the fine was not paid replaced with imprisonment for 3 (three) months based on Article 82 paragraph (1) of Law 17/2016. Monday, 17 December 2018 (https://www.hukumonline.com/klinik/detail/ulasan/lt511430e89651b/tindak-pidanayang-related-relations-pasangan-sesama-tenis-tenis 
3. Continuing the recommendations for the application of article 292 at the Padang District Court expressly implements article 292 for adults and children under five or ten years imprisonment instead of replacing the fines with imprisonment for3 (three) months.

\section{References}

[1] Che Zarrina binti Saari, J. (2015). Peranan Wanita dalam Pengukuhan Akidah Umat Islam. Jurnal Usuluddin.

[2] Coulter, R. W. S., Kenst, K. S., Bowen, D. J., \& Scout. (2014). Research funded by the National Institutes of Health on the health of lesbian, gay, bisexual, and transgender populations. American Journal of Public Health. https://doi.org/10.2105/AJPH.2013.301501

[3] Government of Indonesia. (2016). Lima Poin Utama Revisi UU ITE.

[4] Hajriansyah, H. (2017). Akhlak Terpuji dan Yang Tercela: Telaah Singkat Ihya' Ulumuddin Jilid III. NALAR: Jurnal Peradaban Dan Pemikiran Islam. https://doi.org/10.23971/njppi.v1i1.899

[5] Hallaq, W. B. (2001). Authority, Continuity, and Change in Islamic Law. In Authority, Continuity, and Change in Islamic Law. https://doi.org/10.1017/cbo9780511495557

[6] Hariansah, S. (2018). Social Perspectives; Legal Policy Post-Constitutional Court Decision No. 46/PUU-XIV/2016 Concerning Immoral Provision of Indonesia Criminal Code. Berumpun: International Journal of Social, Politics, and Humanities. https://doi.org/10.33019/berumpun.v1i1.10

[7] Isa, M., Fahmi, A., Yahya, M., \& Jasmi, K. A. (2012). Wanita dan Perkahwinan dalam Islam. Seminar Tamadun 2012.

[8] Koeswinarno, \& Mustolehudin. (2017). Islam, gay, and marginalization: A study on the religious behaviours of gays in Yogyakarta. Indonesian Journal of Islam and Muslim Societies. https://doi.org/10.18326/ijims.v7i1.125-152

[9] Lewis, K., Gonzalez, M., \& Kaufman, J. (2012). Social selection and peer influence in an online social network. Proceedings of the National Academy of Sciences of the United States of America. https://doi.org/10.1073/pnas.1109739109

[10] Mursyid, A. (2015). Ma'rifat al-Nikāḥ: Perspektif Baru Relasi Suami Istri. Manuskripta. https://doi.org/10.33656/manuskripta.v5i1.37

[11] MUSLICH, A. W. (2001). Ayat-ayat Pidana dalam Al-Qur'an. ALQALAM. https://doi.org/10.32678/alqalam.v18i90-91.1463

[12] Rangkuti, R. Y. (2012). Homoseksual dalam Perspektif Hukum Islam. Asy-Syir'ah.

[13] Setyawan, I. (2015). Hukuman Bagi Pelaku Kejahatan Seksual Pada Anak Menurut UndangUndang No. 23 Tahun 2002 Tentang Perlindungan Anak. Kultura.

[14] Siti Aminah. (2015). Pengaruh Pemikiran Fiqh Yusuf Al-Qardhawi di Indonesia. Ummul Quro.

[15] Toomey, R. B., Ryan, C., Diaz, R. M., Card, N. A., \& Russell, S. T. (2010). Gendernonconforming lesbian, gay, bisexual, and transgender youth: School victimization and young adult psychosocial adjustment. Developmental Psychology. https://doi.org/10.1037/a0020705

[16] Yanggo, H. T. (2019). Penyimpangan Seksual (LGBT) Dalam Pandangan Hukum Islam. MISYKAT: Jurnal Ilmu-Ilmu Al-Quran, Hadist, Syari'ah Dan Tarbiyah. https://doi.org/10.33511/misykat.v3n2.1-28 